\title{
Reply: The glacial history of the Dinaric Alps, Montenegro
}

DOI:

10.1016/j.quascirev.2012.06.017

Link to publication record in Manchester Research Explorer

\section{Citation for published version (APA):}

Hughes, P. D., Woodward, J. C., van Calsteren, P. C., \& Thomas, L. E. (2012). Reply: The glacial history of the Dinaric Alps, Montenegro. Quaternary Science Reviews, 49, 111-112.

https://doi.org/10.1016/j.quascirev.2012.06.017

\section{Published in:}

Quaternary Science Reviews

\section{Citing this paper}

Please note that where the full-text provided on Manchester Research Explorer is the Author Accepted Manuscript or Proof version this may differ from the final Published version. If citing, it is advised that you check and use the publisher's definitive version.

\section{General rights}

Copyright and moral rights for the publications made accessible in the Research Explorer are retained by the authors and/or other copyright owners and it is a condition of accessing publications that users recognise and abide by the legal requirements associated with these rights.

\section{Takedown policy}

If you believe that this document breaches copyright please refer to the University of Manchester's Takedown Procedures [http://man.ac.uk/04Y6Bo] or contact uml.scholarlycommunications@manchester.ac.uk providing relevant details, so we can investigate your claim.

\section{OPEN ACCESS}




\section{Correspondence}

\section{Reply: the glacial history of the Dinaric Alps, Montenegro}

We welcome the comments of Djurović (in this volume) and thank him for his interest in our work. The main issue raised by Djurović is the maximum extent of glaciation presented in our paper. It is important to recognise that many of the maximum ice limits identified by us were also mapped and reported by Cvijić (1914, 1917), Liedtke (1962) and in the various maps published by the Geological Survey of Yugoslavia (Osnovna Geološka Karta SFRJ, 1970; Mirković et al., 1979; Živaljević et al., 1981; Mirković and Vujisić, 1989). The accuracy of these earlier observations was confirmed in the field over a five-year campaign (2005-2010). Those authors who have presented evidence of a more restricted glaciation in the Durmitor area (e.g. Marović and Marković, 1972; Menković et al., 2004; Djurović, 2009) and in other parts of Montenegro (Milivojević et al., 2008) have focused their attention on the glacial landforms of the mountain interiors where the evidence is most clearly preserved. The more extensive glaciation of central Montenegro that we propose is also consistent with the recently published findings of extensive low-altitude glaciation on the nearby coastal mountains at Orjen and Lovčen (Hughes et al., 2010; Stepišnik and Žebre, 2011).

Contrary to the views of Djurović, the presence of subrounded and striated pebbles and boulders at certain exposures within the Ninkovići and Žabljak members is entirely consistent with a glacial origin. This designation is in agreement with Cvijić (1914) and Marović and Marković (1972) who identified moraines and ice cover throughout this area in their sketch maps. The sediments described in Hughes et al. (2011) are compatible with a range of subglacial till types set out in Boulton's (1978) classification. Djurović seems to adhere to a rather narrow definition of moraines as surface glacial landforms which are dominated by supraglacial material (supraglacial morainic till in Boulton, 1978). This is typical of cirque and valley glacier moraines - and especially lateral moraines. Further away from the ice source, moraines tend to become dominated by clasts that have undergone substantial subglacial transport. Even for lateral moraines of valley glaciers, it is well established that longer transport distances produce a marked reduction in angularity (Benn and Ballantyne, 1994; Lukas et al., 2012). It is widely recognised that different types of glacial deposits can be dominated by either subangular or subrounded clasts. When used in isolation, these classifications are not especially useful discriminators of landform genesis and must be considered within their wider geomorphological context. In Hughes et al. (2011), all types of moraines/ tills are depicted in Figure 1 as 'glacial deposits'.

DOI of original article: 10.1016/j.quascirev.2012.05.016.
The lowest elevation deposits associated with the most extensive phase of glaciation in central Montenegro display the classic characteristics of subglacial tills, such as poorly sorted diamictons, fine-grained silty matrix, and striated subrounded clasts of variable sizes from pebble to boulder. The abundant fine-grained matrix of finely comminuted limestone bedrock is typical of glacial sediments in the mountains of the Balkan Peninsula (Woodward et al., 1992). Some areas retain a distinct surface morphology that strongly resembles moraines. Middle Pleistocene moraines retain a well-preserved morphology in several places because they are often strongly cemented - a feature utilised for U-series dating here, and in similar settings in Montenegro (Hughes et al., 2010, 2011) and Greece (Woodward et al., 2004; Hughes et al., 2006; Woodward and Hughes et al., 2011).

Djurović (in this volume) asks whether any analyses were undertaken in the Sinjajevina and Prekornica massifs. The Sinjajevina massif, in particular, was studied in detail. This included Useries dating of cements in the terminal moraine at Kolašin that was first recognised by Cvijić $(1914,1917)$. The entire summit plateau and surrounding valleys were also explored and carefully mapped. It was not possible to publish these details in Hughes et al. (2011), which already reaches 20 pages in length. Our observation that the entire Sinjajevina plateau was glaciated, and not just the cirques and valleys, is supported by the presence of glaciokarst landforms on the plateau (these have also been recorded by Telbisz, 2010a,b,c) as well as the presence of till and large ( $>1 \mathrm{~m}$ ) perched glacial boulders close to the watershed. The Moračke Planine area was also mapped along with the Maganik and Prekornica massifs (see Fig. 1 in Hughes et al., 2011). The western parts of this area were also mapped by Liedtke (1962) who argued that the Lukavica Plateau was once covered by ice. Liedtke (1962) also identified the moraines in the Morakovo valley. This valley would have drained an ice dome between Prekornica and Maganik. Indeed, Liedtke (1962, Abb. 2) recognised that ice emanated from the Prekornica, Miljevac and Maganik areas and converged in the Morakovo valley. Furthermore, contrary to the suggestions of Djurović, there is evidence of subglacial bedrock scouring to the south of this ice centre and east of Prekornica.

The uplift question is intriguing yet extremely difficult to quantify with any degree of accuracy. Whilst this issue has no bearing on our conclusion that extensive ice masses formed over Montenegro, it is of course relevant to the palaeoclimatic inferences that are made from the glacial geomorphological evidence. The impact of uplift on reconstructing ELAs is discussed in our paper on page 3410 .

The arguments made by Djurović and co-workers (e.g. Djurović, in this volume; Milivojević and Djurović, 2010) for a more restricted 
glaciation involve a major re-interpretation of many years of field observations by previous workers such as Cvijić (1914, 1917), Liedtke (1962) and the Yugoslavia Geological Survey (Osnovna Geološka Karta SFRJ, 1970; Mirković et al., 1979; Živaljević et al., 1981; Mirković and Vujisić, 1989). Of course, since much of this work was undertaken the wider academic context has changed dramatically - especially with regards to geochronology - but the basic field observations still hold in many areas.

The assertion of Djurovic that the thickness of the ice mass presented in Hughes et al. (2011) is contradictory with the size and scale of glacial erosive forms cannot be sustained. The large glacial troughs at Boričje (Durmitor), Komarnica (Durmitor), Lipovo (Sinjajevina), Morakovo (Prekornica/Maganik), Plav-Gusinje (Prokletije), amongst many others that lie at or below c. $1000 \mathrm{~m}$ a.s.l. all support an extensive glaciation in Montenegro. An ice cap submerging the landscape is required in order to produce the ice surface relief needed to reach and erode some of these valleys. This is supported by a variety of field evidence. For example, whilst Djurović (2009) recognises that the Komarnica valley has been glaciated, he does not document the clear ice-moulding of the high-level areas above this deep valley, such as the summit ridges of Lojanik (2091 $\mathrm{m}$ a.s.l.) and Boljske grede (2091 m a.s.l.) (see Fig. 3C in Hughes et al., 2011) A former ice cap several hundreds of metres thick has also been recognised on Sinjajejvina by Telbisz (2010b,c).

The glacial landforms of Montenegro are some of the most impressive in Europe. The mountain interiors have been moulded by multiple phases of glacial erosion. The clearest glacial erosional forms are restricted to the mountain interiors because of multiple erosional events during different glacial cycles. This contrasts with the distal areas which have experienced fewer glacial advances and may explain why Milivojević and Djurović (2010, cited in Djurović, in this volume) restrict their zone of glacial processes to the landscape above $1750 \mathrm{~m}$ a.s.l.

We have presented the first geochronological framework for Pleistocene glaciations in Montenegro supported by more than $30 \mathrm{U}$-series ages. There is evidence for glaciation in at least three cold stages and this represents a key advance on previous work. It is likely that glaciers developed in the mountains of Montenegro during all of the cold stages of the Middle and Late Pleistocene. Indeed, a small glacier still exists today on Durmitor (Hughes, 2007,2008 ). Hughes et al. (2011) build on the pioneering observations of earlier scholars such as Cvijić $(1914,1917)$ and Liedtke (1962) and the various maps published by the Yugoslavia Geological Survey in the 1970s and 1980s. There is strong evidence for repeated and extensive glaciation in Montenegro. The ice cap model we have presented is the best reconstruction of the central Montenegro ice masses given the evidence available. We will publish the evidence from all the major massifs in the region in detail in due course.

\section{References}

Benn, D.I., Ballantyne, C.K., 1994. Reconstructing the transport history of glacigenic sediments: a new approach based on the co-variance of clast form indices. Sedimentary Geology 91, 215-227.

Boulton, G.S., 1978. Boulder shapes and grain-size distributions of debris as indicators of transport paths through a glacier and till genesis. Sedimentology 25 , 773-799.

Cvijić, J., 1914. Eiszeitliche Vergletscherung der Gebirgsgruppen von Prokletije bis Durmitor. Maßstab 1:200,000. K.u.k. Militärgeographischen Institutes, Wien.

Cvijić, J., 1917. L'époque glaciaire dans la péninsule des Balkanique. Annales de Géographie 26, 189-218.

Djurović, P., 2009. Reconstruction of the Pleistocene glaciers of Mt. Durmitor in Montenegro. Acta Geographica Slovenica 49-2, 263-289.
Djurović. P. Comment on: "The glacial history of the Dinaric Alps, Montenegro" by P.D. Hughes, J.C. Woodward, P.C. van Calsteren, L.E. Thomas [Quaternary Science Reviews 30 (2011), 3393-3412], Quaternary Science Reviews (2012), http://dx. doi.org/10.1016/j.quascirev.2012.05.016.

Hughes, P.D., 2007. Recent behaviour of the Debeli Namet glacier, Durmitor, Montenegro. Earth Surface Processes and Landforms 10, 1593-1602.

Hughes, P.D., 2008. Response of a Montenegro glacier to extreme summer heatwaves in 2003 and 2007. Geografiska Annaler 90A, 259-267.

Hughes, P.D., Woodward, J.C., Gibbard, P.L., Macklin, M.G., Gilmour, M.A., Smith, G.R. 2006. The glacial history of the Pindus Mountains, Greece. Journal of Geology $114,413-434$

Hughes, P.D., Woodward, J.C., van Calsteren, P.C., Thomas, L.E., Adamson, K., 2010 Pleistocene ice caps on the coastal mountains of the Adriatic Sea: palaeoclimatic and wider palaeoenvironmental implications. Quaternary Science Reviews 29, 3690-3708.

Hughes, P.D., Woodward, J.C., van Calsteren, P.C., Thomas, L.E., 2011. The glacial history of the Dinaric Alps, Montenegro. Quaternary Science Reviews 30, 3393-3412.

Liedtke, H., 1962. Eisrand und Karstpoljen am Westrand der Lukavica-Hochfläche. Erdkunde XVI, 289-298.

Lukas, S., Graf, A., Coray, S., Schlüchter, C., 2012. Genesis, stability and preservation potential of large lateral moraines of Alpine valleys - towards a unifying theory based on Findelengletcher, Switzerland. Quaternary Science Reviews 38, 27-48.

Marović, M., Marković, M., 1972. Glacijalna morfologija šire oblasti Durmitora. Geološki anali Balkanskog poluostrva 37, 37-48.

Menković, L., Marković, M., Čupković, T., Pavlović, R., Trivić, B., Banjac, N., 2004 Glacial morphology of Serbia (Yugoslavia), with comments on the Pleistocene glaciation of Montenegro, Macedonia and Albania. In: Ehlers, J., Gibbard, P.L. (Eds.), Quaternary Glaciations-Extent and Chronology. Part I: Europe. Elsevier Amsterdam, pp. 379-384.

Mirković, M., Vujisić, P., 1989. Osnovna geološka karta Jugoslavije. Žabljak, Sheet K34-27. Savezni geološki zavod, Beograd.

Milivojević, M., Djurović, P., 2010. Glacijalna I periglacijalna morfologia - indicator promene klime na planinama Crne Gore. In: Zbornik referata sa Medjunarodnog simpozijuma “Geoekologija - vijek, teorijski I aplikativni zadaci”, Zabljak, pp. 536-543.

Milivojević, M., Menković, L., Ćalić, J., 2008. Pleistocene glacial relief of the central part of Mt. Prokletije (Albanian Alps). Quaternary International 190, 112-122.

Mirković, M., Pajović, M., Nalezić, M., 1979. Osnovna geološka karta SFRJ. Gacko, Sheet K34-26. Savezni geološki zavod, Beograd.

Osnovna Geološka Karta SFRJ, 1970. Šavnik, Sheet K34-39. Saveznog geološkog zavoda Beograd.

Stepišnik, U., Žebre, M., 2011. Glaciokras Lovčena. E-GeograFF 2. Univerza v Ljubljani, Filozofska fakulteta, 82 pp. http://geo.ff.uni-lj.si/sites/default/files/ glaciokras_lovcena_0.pdf

Telbisz, T., 2010a. Morphology and GIS-analysis of closed depressions in Sinjajevina Mts (Montenegro). Karst Development 1 (1), 41-47.

Telbisz, T., 2010b. Glacio-karst features of the Sinjajevina Mts (Montenegro): an overview and DEM analysis. Karst Development 1 (2), 17-22.

Telbisz, T., 2010c. A Montenegrói Sinjajevina-Karsztfennsík Felszínalaktani Vizsgálata Terepi És Térinformatikai Módszerekkel. Karsztfejlödés XV, Szombathely, 85-101.

Woodward, J.C., Lewin, J., Macklin, M.G., 1992. Alluvial sediment sources in a glaciated catchment: the Voidomatis basin, northwest Greece. Earth Surface Processes and Landforms 17, 205-216.

Woodward, J.C., Macklin, M.G., Smith, G.R., 2004. Pleistocene glaciation in the mountains of Greece. In: Ehlers, J., Gibbard, P.L. (Eds.), Quaternary Glaciations - Extent and Chronology: Part 1. Elsevier, Amsterdam, pp. 155-173.

Živaljević, M., Vujisić, P., Mirković, M., Đokić, V., Čepić, M., 1981. Osnovna geološka karta SFRJ. Ivangrad, Sheet K34-40. Savezni geološki zavod, Beograd.

P.D. Hughes*, J.C. Woodward Quaternary Environments and Geoarchaeology Research Group, Geography, School of Environment and Development, The University of Manchester, Manchester M13 9PL, UK

P.C. van Calsteren, L.E. Thomas Natural Environment Research Council, Open University Uranium-Series Facility, Department of Earth and Environmental Sciences, The Open University, Milton Keynes MK7 6AA, UK

* Corresponding author E-mail address: philip.hughes@manchester.ac.uk (P.D. Hughes) Available online 21 July 2012 